Hal : $18-22$

\title{
PENGARUH PENGGUNAAN MEDIA VIDEO ANIMASI TERHADAP RESPON SISWA DALAM PEMBELAJARAN MATEMATIKA PADA MATERI OPERASI BILANGAN BULAT
}

\section{THE EFFECT OF USING ANIMATION VIDEO MEDIA ON STUDENT RESPONSES IN MATHEMATICS LEARNING ON OPERATING NUMBER OF ROUND NUMBERS}

\author{
PUJI NINGSIH SRI HARIATI', ROHANITA LILY², SAFITRI ISLAMIANI ${ }^{3}$
}

${ }^{123}$ FKIP Universitas Labuhanbatu Jalan Sisingamangaraja No. 126A, KM. 3,5 Aek Tapa Rantauprapat, email: 1'srihariatipujiningsih@gmail.com, ${ }^{2}$ Irohanita30@gmail.com, ${ }^{3}$ Islamiani.safitri@gmail.com

\begin{abstract}
Abstrak
Penelitian ini bertujuan untuk mengetahui respon siswa dengan menggunakan media video animasi di SMP Swasta Pemda Rantauprapat. Metode yang digunakan adalah metode penelitian eksperimen dengan bentuk one-Shot Case Study. Subjek penelitian ini adalah kelas VII C yang berjumlah 31 siswa. Indikator respon siswa yang diteliti adalah siswa mendengarkan penjelasan pembelajaran menggunakan media, siswa aktif dan tanggap dalam pembelajaran, siswa berani bertanya, dan siswa berani menyampaikan pendapat. Analisis terhadap hasil angket menunjukkan adanya peningkatan respon siswa melalui penggunaan media video animasi dalam pembelajaran matematika. Peningkatan ini dibuktikan dengan hasil rata-rata yang di dapat dari angket yaitu 67,58 (kategori tinggi). Dan dari data hasil observasi di dapatkan data yaitu 81,25\% (Indikator Sangat Baik). Sedangkan hasil dari wawancara mendapat hasil jawaban yang sangat baik.
\end{abstract}

Kata kunci : Respon Siswa, Media Video Animasi

\begin{abstract}
This study aims to determine the response of students using animated video media at the Rantauprapat Regional Government Private Middle School. The method used is an experimental research method with a one-Shot Case Study form. The subjects of this study were class VII C, totaling 31 students. The response indicators of the students studied were students listening to the explanation of learning using media, active and responsive students in learning, students daring to ask questions, and students daring to express their opinions. Analysis of the questionnaire results showed an increase in student responses through the use of animated video media in mathematics learning. This increase is evidenced by the average results obtained from the questionnaire namely 67.58 (high category). And from the observation data, the data is $81.25 \%$ (Very Good Indicator). While the results of the interview got the results of the answers that were very good.
\end{abstract}

Key Words : Student Response, Animated Video Media.

\section{Pendahuluan}

Pembelajaran matematika pada hakikatnya adalah proses yang sengaja dirancang dengan tujuan untuk menciptakan suasana lingkungan memungkinkan seorang peserta didik melaksanakan kegiatan belajar matematika, dan proses tersebut berpusat pada guru mengajar matematika. Dalam pembelajaran yang dilakukan disekolah, pembelajaran matematika dimaksudkan sebagai proses yang sengaja dirancang dengan tujuan untuk menciptakan suasana lingkungan yang memungkinkan kagiatan siswa belajar matematika sekolah [8].

Respon terhadap media pembelajaran dapat dilihat dari ekspresi, pendapat langsung mengenai ketertarikan terhadap media, kemudahan untuk memahami pesan yang ingin disampaikan melalui media, dan bagaimana motivasi siswa setelah menyimak penggunaan media tersebut [2]. Media pembelajaran digunakan untuk dapat memperjelas penyajian pesan dan informasi sehingga adalam waktu pembelajaran yang pendek akan banyak informasi yang tersampaikan. 
Salah satu media pembelajaran yang bisa digunakan adalah video. Video merupakan gambar-gambar dalam frame, dimana frame demi frame diproyeksikan melalui lensa proyektor secara mekanis sehingga pada layar terlihat gambar hidup [3]. Video animasi termasuk media audio visual. Melalui media audio visual, siswa dapat melihat dan mendengarkan film, sehingga siswa tidak hanya mendengarkan ceramah dari guru. Di dalam video animasi memuat gambar-gambar yang berwarna, sehingga siswa diharapkan senang dan dapat fokus terhadap materi pelajaran [4]. Pada penelitian ini, peneliti menggunakan media video animasi dalam kegiatan pembelajaran. Tujuan penelitian ini untuk mengetahui respon siswa dengan menggunakan media video animasi dalam pembelajaran matematika pada materi operasi bilangan bulat.

\section{Metode Penelitian}

Metode penelitian yang digunakan adalah penelitian kuantitatif dengan pendekatan eksperimen dengan bentuk one-shot case study. Tempat dilaksanakannya penelitian ini di SMP Swasta Pemda Rantauprapat dengan subjek penelitian adalah siswa kelas VII C yang berjumlah 31 orang. Adapun waktu penelitiannya pada bulan Mei 2019 di semester genap.

Instrumen yang digunakan adalah lembar angket, observasi dan wawancara. Sedangkan teknik analisis data yang digunakan adalah data yang di dapat dari hasil angket yaitu menggunakan skala likert kemudian dengan analisis kualitatif deskriptif untuk menggambarkan respon siswa yang didapat dari hasil pengamatan observasi dan hasil wawancara. Jenis analisisnya menggunakan analisis perentase dengan menggunakan rumus [5] :

$$
\mathrm{P}=\frac{f}{N} \times 100 \%
$$

Skor persentase kemudian dicocokkan dengan kriteria persentase respon siswa yaitu:

Tabel 1. Kriteria Persentasi Respon Siswa

\begin{tabular}{|c|c|}
\hline Kategori & Rentang \\
\hline Sangat Tinggi & $84-100$ \\
\hline Tinggi & $61-80$ \\
\hline Sedang & $41-60$ \\
\hline Rendah & $21-40$ \\
\hline Sangat Rendah & $0-20$ \\
\hline
\end{tabular}

\section{Hasil Penelitian dan Pembahasan}

\section{Hasil Penelitian}

Dalam penelitian ini analisis yang di gunakan ada 2 jenis yaitu analisis data kualitatif dan data kuantitatif. Data yang dikumpulkan peneliti dalam penelitian ini yang berupa respon siswa yang diperoleh dari menggunakan kousioner (angket), obsevasi dan wawancara. Langkah pertama dalam pengambilan data adalah dengan memberikan perlakuan, dalam hal ini bentuk perlakuannya adalah dengan pembelajaran menggunakan media video animasi terhadap respon siswa pada materi operasi bilangan bulat di SMP Swasta Pemda. Saat dalam perlakuan peneliti juga melakukan observasi terhadap siswa. Langkah selanjutnya adalah membagikan kousioner (angket) kepada seluruh siswa. Langkah terakhir adalah melakukan wawancara kepada guru dan siswa.

Adapun hasil angket respon siswa diperoleh dari pemberian angket respon siswa setelah diberi pembelajaran dengan menggunakan media video animasi yang terdiri dari 25 butir pertanyaan, dimana 14 butir pernyatan positif dan 11 butir pernyataan negatif yang dapat dikelompokkan menjadi empat kategori yaitu kategori sangat kuat, kategori kuat, kategori cukup, kategori lemah, dan kategori sangat lemah. Dengan merujuk pada kriteria hasil angket respon siswa sebagai berikut : 
Tabel 2. Kategori nilai respon siswa

\begin{tabular}{|c|c|}
\hline Kategori & Rentang \\
\hline Sangat Tinggi & $84-100$ \\
\hline Tinggi & $61-80$ \\
\hline Sedang & $41-60$ \\
\hline Rendah & $21-40$ \\
\hline Sangat Rendah & $0-20$ \\
\hline
\end{tabular}

Dalam menganalisis respon siswa digunakan Skala Likert. Jawaban setiap item instrument yang menggunakan Skala Likert mempunyai gradasi sangat setuju, setuju, tidak setuju dan sangat tidak setuju. Angket berisi pernyataan yang berkaitan dengan respon siswa terhadap pembelajaran matematika menggunakan media video animasi.

Tabel 3. Data hasil angket respon siswa

\begin{tabular}{|c|c|c|c|c|c|}
\hline No & Kode siswa & Nilai & No & Kode Siswa & Nilai \\
\hline 1 & 1 & 65 & 26 & 26 & 62 \\
\hline 2 & 2 & 63 & 27 & 27 & 64 \\
\hline 3 & 3 & 62 & 28 & 28 & 65 \\
\hline 4 & 4 & 68 & 29 & 29 & 62 \\
\hline 5 & 5 & 72 & 30 & 30 & 61 \\
\hline 6 & 6 & 69 & 31 & 31 & 64 \\
\hline
\end{tabular}

Berdasarkan data di atas dapat disajikan gambar frekwensinya sebagai berikut :

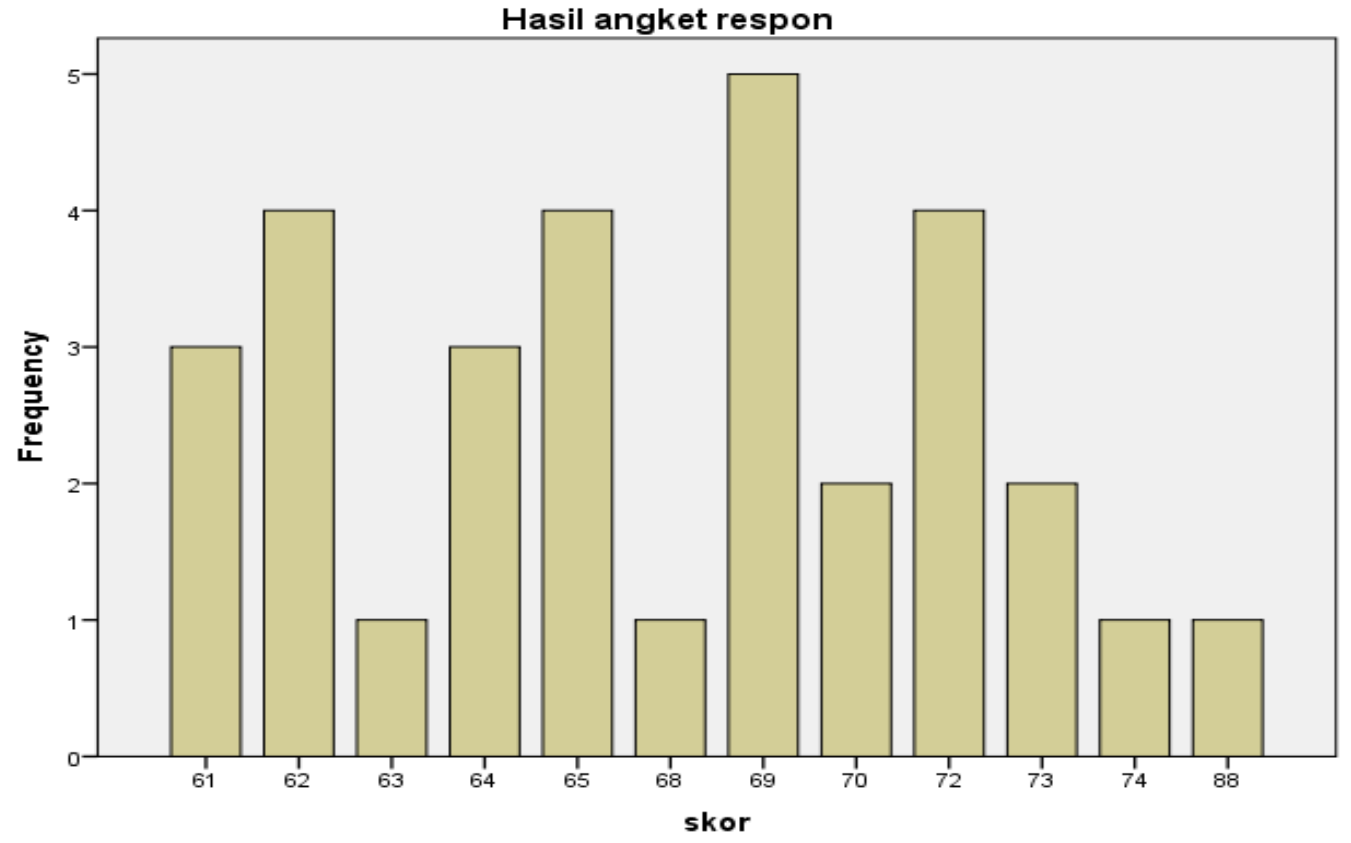

Gambar 1. Frekwensi Hasil Angket Respon Siswa

Pada gambar 1 menunjukkan bahwa siswa siswa dengan skor 69 memiliki frekwensi yang tinggi, data ini dapat dihitung rata-rata hasil angket untuk mengetahui kategori nilai angket tersebut. Dari data frekwensi ini juga dapat dihitung rata-rata data tersebut mengetahui kategorinya. Berikut adalah rata-rata ketercapaian pembelajaran matematika yang telah dihitung dengan perhitungan statistik bantuan computer program SPSS versi 20.0 for windows. 
Tabel 4. Angket Respon Siswa

\begin{tabular}{|c|c|c|}
\hline \multicolumn{3}{|c|}{ Statistics } \\
\hline \multicolumn{3}{|c|}{ Skor } \\
\hline \multirow{2}{*}{$N$} & Valid & 31 \\
\hline & Missing & 0 \\
\hline \multicolumn{2}{|c|}{ Mean } & 67.58 \\
\hline \multicolumn{2}{|c|}{ Median } & 68.00 \\
\hline \multicolumn{2}{|c|}{ Minimum } & 61 \\
\hline \multicolumn{2}{|c|}{ Maximum } & 88 \\
\hline
\end{tabular}

Berdasarkan tabel 4.3 tabel statistic dan perhitungan di atas dapat dilihat rata-rata hasil angket sebesar 67,58 . Dengan $\mathrm{N}=31$ atau jumlah siswa 31 , dengan nilai minimum 61 dan nilai maksimum 88 . Menurut tabel 4.1 di jelaskan bahwa respon siswa termasuk dalam kategori Tinggi.

Observasi dilakukan untuk mengetahui kelayakan media interaktif berbasis media video animasi berdasarkan tanggapan dan respon guru dan siswa saat penggunaan media pembelajaran media video animasi dalam pembelajaran matematika. Skala Penilaian: BS = Baik Sekali $\quad B=B a i k \quad C=S e d a n g$. Berdasarkan skala penilaian, dari 16 indikator hanya 13 yang muncul. Bila dipersentasekan $\frac{13}{16} \times 100 \%$ maka hasilnya $81,25 \%$. Dengan demikian bahwa penggunaan media video animasi menunjukkan sangat baik digunakan untuk meningkatkan respon siswa dalam pemebalajaran matematika.

\section{Pembahasan}

Penelitian ini tentang pembelajaran matematika dengan media pembelajaran video animasi yang dilaksanakan dikelas VII C SMP SWASTA PEMDA Rantauprapat. Adapun waktu penelitian dilaksanakan pada semester genap tahun pembelajaran 2018/2019 pada bulan Mei. Adapaun materi yang digunakan dalam penelitian ini adalah Operasi Bilangan Bulat.

Dalam pembelajaran matematika digunakan media video animasi berdasarkan hasil analisis yang di lakukan dengan responden sebanyak 31 orang siswa di dapat rata-rata 67,58 (Tinggi). Ini menunjukkan bahwa media video animasi mampu meningkatkan respon siswa dalam pembelajaran matematika. Didapat nilai manimum 61 dan nilai maksimumnya 88 .

Setelah mengumpulkan data melalui angket didapat juga hasil dari observasi di dapat hasil $81,25 \%$ dengan kategori sangat baik pada setiap indikator nya. Namun dalam bebarapa indikator masih terdapat indikator yang belum tampak dan memerlukan perbaikan-perbaikan terutama pada indikator 6, 7, 8 dan 9 sama sekali belum muncul sama sekali.

Setelah di kumpulkan data dari observasi dan mendapatkan hasilnya selanjutnya dilakukan menggunakan wawancara. Setelah di kumpulkan data-data dari wawancara di lihat secara keseluruhan respon siswa dalam penggunaan media video animasi menunjukkan hasil yang baik.

Berdasarkan hasil analisis dapat disimpulkan bahwa pembelajaran menggunakan media video animasi pada materi operasi bilangan bulat memiliki tampilan yang menarik dan menyenangkan karena terdapat gambar, animasi dan suara. Siswa juga menyatakan bahwa pembelajaran menggunakan media video animasi ini dapat membantu memahami materi. Respon siswa terhadap pembelajaran menggunakan media video animasi sangat baik dan mereka juga antusias. Karena siswa dapat menggunakan pembelajaran media video animasi ini dirumah dan dapat juga digunakan dimana saja apabila mereka menggunakan laptop. Hal ini sesuai dengan hasil penelitian yang menyatakan bahwa media video animasi mampu membuat siswa lebih bersemangat sehingga kreativitas siswa meningkat [6].

Penelitian yang telah dilakukan, peneliti telah berusaha semaksimal mungkin dalam melaksanakan penelitian. Adapun kendala-kendala dalam penelitian adalah pembelajaran dengan menggunakan media video animasi belum pernah dilakukan sehingga dalam proses belajar belum maksimal didalam berinteraksi dengan media video animasi dan menyampaikan pendapatnya[7]. 


\section{Kesimpulan}

Berdasarkan hasil penelitian yang dilakukan peneliti pada siswa kelas VII C SMP SWASTA PEMDA Rantauprapat tahun pembelajaran 2018/2019 diperoleh kesimpulan sebagai berikut :

1. Pengaruh media video animasi terhadap respon siswa menggunakan media video animasi dalam pembelajaran matematika pada materi operasi bilangan bulat sangat baik dilihat dari data hasil observasi yang di dapat yaitu $81,25 \%$. Setiap indikator dari lembar observasi juga mendapat nilai sangat baik. Namun dalam bebarapa indikator masih terdapat indikator yang belum tampak dan memerlukan perbaikan-perbaikan terutama pada indikator 6,7,8 dan 9 sama sekali belum muncul sama sekali.

2. Diketahui respon siswa terhadap media video animasi dalam pembelajaran matematika pada materi operasi bilangan bulat sangat tinggi. Hal ini dilihat dari hasil data angket dan wawancara dimana hasil data angket menunjukkan hasil rata-rata 67,58 dengan kategori tinggi. Dengan nilai minimum 61 dan nilai maksimumnya 88 dimana jumlah siswanya adalah 31 orang. Sedangkan dari hasil wawancara dengan guru dan siswa di dapat hasil jawaban yang sangat baik. Namun masih ada kekurangan yaitu suara dalam video masih perlu menggunakan alat bantu lain misalnya speaker agar suara terdengar jelas.

\section{Daftar Pustaka}

[1] Wahyudi, A. (2013). Penggunaan Media Audio Visual Dalam Peningkatan Hasil Belajar Matematika. Kalam Cendekia PGSD Kebumen , 1-7.

[2] G.P. M. d. (2013). Respon Siswa Terhadap Penggunaan Media Pembelajaran Oleh Guru IPA Biologi di Kecamatan Kendawanga. Wahana-Bio, 1-10.

[3] Arsyad, A. (2005). Media Pembelajaran. Jakarta: PT Grafindo Persada.

[4] Ranang. (2010). Animasi Kartun dari Analog Sampai Digital. Jakarta: PT. Indeks.

[5] Sugiyono. (2010). Metode Penelitian Kuantitati,f Kualitatif dan R\&D. Bandung: Alfabeta.

[6] Safitri, I., Rohani, Suharni, S., \& Lubis, K. (2019). The Effectiveness of Android Application as a Student Aid Tool in Understanding Physics Project Assignments. Jurnal Pendidikan IPA Indonesia (JPII) , 512-520.

[7] Safitri, I. (2017). Pengaruh Media Audio Visual Terhadap Kemampuan Pemahaman Konsep Matematika di Kelas X SMA Muhammadiyah 10 Rantauprapat Tahun Pembealjaran 2016/2017. JURNAL PEMBELAJARAN DAN MATEMATIKA SIGMA (JPMS) , 14-23. 